\title{
PENGARUH PEMBERIAN SMOOTHIESMATONIS DI PUSKESMAS KOTA PALEMBANG
}

\author{
Monica Julia Irawan, Susyani, Podojoyo \\ Politeknik Kementerian Kesehatan Palembang, Jurusan gizi \\ Jl. Sukabangun I No 3623 KM 6,5, Palembang 30151, Indonesia. \\ susyani@poltekkespalembang.ac.id
}

\begin{abstract}
Hypertension is a medical condition in which the systolic blood pressure is $\geq$ $140 \mathrm{mmHg}$ and the diastolic blood pressure is $\geq 90 \mathrm{mmHg}$. It is caused by several factors such as overweight, over consumption of sodium, lacks of physical activities, smoking, alcohol consumption, age, sex, and ancestry. The treatment for hypertension consists of pharmacological therapy and non-pharmacological therapy. to identify the effect on Smatonis smoothie on the blood pressure of hypertensionThe type of this research is quasi experiment with pre-test and post-test with control group as its design. This research was done in January-March 2019. The data analysis technique used SPSS with Paired t-test. Based on statistical test results, there are differences in systolic and diastolic blood pressure in the treatment group before and after the smootieSmatonis were given. In the control group there was no statistically significant decrease in blood pressure. Reguler consumption of Smatonis smoothies can reduce blood pressure in people with hypertension.
\end{abstract}

Keywords: Blood pressure, Hypertension, Smatonis smoothie.

\begin{abstract}
Abstrak: Hipertensi adalah suatu kondisi medis dimana tekanan darah Sistolik $\geq 140$ $\mathrm{mmHg}$ dan Diastolik $\geq 90 \mathrm{mmHg}$, yang disebabkan oleh beberapa faktor seperti kegemukan, konsumsi natrium berlebih, kurangnyaaktifitasfisik, merokok, konsumsi alkohol, faktor usia, jenis kelamin dan keturunan. Pengobatan hipertensi terdiri dari terapi farmakologi dan non-farmakologi. Untuk mengetahui pengaruh pemberian smoothie smatonisterhadap tekanan darah penderita hipertensi. Penelitian ini merupakan penelitian quasi experiment dengan rancangan pre and postest with control group, yang dilakukan pada bulan Januari-Maret 2019. Analisis data menggunakan program SPSS dengan paired t-test. Berdasarkan hasil uji statistic, ternyata ada perbedaan yang bermakna tekanan darah sistolik dan diastolic pada kelompok perlakuan sebelum dan sesudah diberikan perakuan berupa smoothie smatonis. Pada kelompok control tidak terjadi perurunan tekanan darah yang bermakna secara statistic. KonsumsiSmoothie Smatonis secararutindapat menurunkan tekanan darah pada penderita hipertensi di Kota Palembang.
\end{abstract}

Kata kunci: Hipertensi, Tekanan darah, Smoothie Smatonis.

Hipertensi atau darah tinggi adalah suatu kondisi medis dimana tekanan darah Sistolik $\geq 140 \mathrm{mmHg}$ dan Diastolik $\geq 90 \mathrm{mmHg}$. Sebanyak $23,3 \%$ penduduk berusia $\geq 18$ tahun di Indonesia mengalami hipertensi dan $63,2 \%$ diantaranya belum terukur dan terdiagnosis oleh tenaga kesehatan (Riskesdas, 2013).
WHO 2013menyebutkanbahwa, prevalensi hipertensi pada orang dewasa di Asia Tenggara sebesar 36\%. Berdasarkan data Riskesdas (2013), penderita hipertensi di Indonesia sebanyak 31,7\%, sedangkan di Provinsi Sumatera Selatan khususnya kota Palembang tercatat prevalensi penyakit tidak menular (PTM) tertinggi per 10.000 
penduduk adalah Hipertensi (54,3\%). Pada tahun 2011 di Kota Palembangkasus hipertensi tertinggi terdapat di Puskesmas Sekip dengan jumlah kasus 5.128 pada tahun 2011.Berdasarkan hasil penelitian yang diadakan di Palembang tahun 2014 menunjukkan bahwa prevalensi hipertensi di Palembang sebesar $14,4 \%$ dari 1210 responden yang berumur diatas 15 tahun.

Pengobatan hipertensi terdiri dari farmakologi dan non-farmakologi. pengobatan farmakologi yang lazim digunakan antara lain diuretik, $\beta$-blocker, Angiotensin Converting Enzyme (ACEI), penghambat reseptor angiotensin (ARB), dan antagonis kalsium (CCB) (Saseen, 2009).

Salah satu buah yang mengandung kalium yang tinggi dan dipercaya mampu menurunkan tekanan darah yaitu buah Semangka, Tomat, dan Jeruk manis. Selain kandungan kalium, semangka, tomat dan jeruk manis juga mengandung serat, dan tinggi Vitamin C. Smoothie Smatonis adalah smoothie adalahSmoothie yang terbuat dari 250 gram semangka, 100 gram tomat, dan 100 gram jeruk manis, yang diberikan kepada kelompok intervensi 1x sehari selama 7 hari berturut-turut dengan kandungan nilai gizi energi : $135 \mathrm{kkal}$, Vitamin C : $74 \mathrm{mg}$, Serat : 2.8 gram, Natrium : 31.5 gram, Kalium : 931.8mg.

Kalium berfungsi meretensi natrium dan air sehingga menyebabkan terjadinya penurunan volume plasma, curah jantung, tekanan perifer, dan tekanan darah (Aryanti, M, 2012). Serat dapat mengurangi pemasukan energy sehingga tubuh merasaken yang lebih lama sehingga tubuh terhindar dari risiko obesitas yang pada akhirnya dapat menurunkan risiko hipertensi (Almatsier, 2009). Sedangkan vitamin C dapat menurunkan tekanan darah dikarenakan memiliki sifat antioksidan yaitu dengan cara memperbaiki disfungsi yang terjadi di endotel (Monica, 2009).

\section{BAHAN DAN CARA KERJA}

Jenis penelitian ini adaahquasi eksperiment dengan rancangan rancangan pretest and postest with control group. Variabel bebas dalam penelitian ini adalah Smoothie Smatonis. Pelaksanaan penelitian dilakukan pada bulan Januari-Maret 2019.

Responden pada penelitian ini adalah penderita hipertensi yang berobat jalan di Puskesmas Sekip Palembang. Kriteria inklusi penelitian ini antara lain : pasien hipertensi yang mendapatkan obat antihipertensi,berusia $\geq 18$ tahun, hipertensi grade I dan grade II, dan tidak memiliki komplikasi.

Besar sampel dalam penelitian ini dihitung dengan menggunakan rumus Lameshow (1997), dan didapat 34 orang untuk kelompok perlakuan dan 34 orang untuk kelompok control, teknikpenentuan responden menggunakan simple random sampling. Kelompok perlakuan adalah 
kelompok responden yang mendapatkan perlakuan pemberian smoothie Smatonis sebagai selingan pagi selama 7 hariberturutturut dan mendapatkan obat anti-hipertensi dari puskesmas. Sedangkan kelompok kontrol adalah kelompok respondenyang tidak mendapatkan smoothie Smatonis tetapi mendapatkan obat anti hipertensidaripuskesmas.

Tekanan darah responden diukur menggunakan alat sphygmomanometer digital sebelum dilakukan intervensi kemudian diukur kembali setelah diberikan intervensi selama 7 hari dan dilakukan oleh petugas kesehatan terlatih dan berpengalaman. Karakteristik responden dan asupan responden dianalisis menggunakan analisis deskriptif sedangkan perbedaan tekanan darah sebelum dan sesudah intervensi kedua kelompok diuji dengan paired sample t-test.

HASIL

Karakteristik Responden dalam penelitian ini disajikan dalam tabel 1.

Tabel 1. Karakteristik Respoden

\begin{tabular}{lcccc}
\hline & \multicolumn{4}{c}{ Kelompok } \\
\cline { 2 - 5 } $\begin{array}{l}\text { Karakteristik } \\
\text { Responden }\end{array}$ & \multicolumn{2}{c}{ Perlakuan } & \multicolumn{2}{c}{ Kontrol } \\
Umur & $\mathrm{n}$ & $\%$ & $\mathrm{n}$ & $\%$ \\
$<40$ tahun & 6 & 17.6 & 1 & 2.9 \\
$\geq 40$ tahun & 28 & 82.4 & 33 & 97.1 \\
Jenis kelamin & & & & \\
Laki-laki & 15 & 44.1 & 11 & 32.4 \\
Perempuan & 19 & 55.9 & 23 & 67.6 \\
\hline
\end{tabular}

\section{Asupan Responden}

Asupan respondenterdiri dari asupan energi, protein, karbohidrat, lemak, natrium, kalium, serat dan vitamin $\mathrm{C}$, disajikan dalam tabel 2 .

Tabel 2. Asupan zatgizi responden

\begin{tabular}{llcccc}
\hline \multirow{2}{*}{ Asupan } & & \multicolumn{4}{c}{ Kelompok } \\
\cline { 3 - 6 } Energi & & \multicolumn{2}{c}{ Perlakuan } & \multicolumn{2}{c}{ Kontrol } \\
& Baik & n & $\%$ & $\mathrm{n}$ & $\%$ \\
& Kurang & 10 & 29.4 & 7 & 20.6 \\
Protein & Baik & 12 & 35.3 & 10 & 29.4 \\
& Kurang & 22 & 64.7 & 24 & 70.6 \\
Lemak & Baik & 9 & 26.5 & 5 & 14.7 \\
& Kurang & 25 & 73.5 & 29 & 85.3 \\
Karbo & Baik & 25 & 73.5 & 29 & 85.3 \\
Hidrat & Kurang & 9 & 26.5 & 5 & 14.7 \\
Natriu & Baik & 0 & 0 & 3 & 8.8 \\
m & & & & & \\
\multirow{2}{*}{ Kaliu } & Kurang & 34 & 100 & 31 & 91.2 \\
m & Baik & 0 & 0 & 0 & 0 \\
& Kurang & 34 & 100 & 34 & 100.0 \\
Serat & Baik & 2 & 5.9 & 0 & 0 \\
& Kurang & 32 & 94.1 & 34 & 100.0 \\
Vit C & Baik & 30 & 88.2 & 6 & 17.6 \\
& Kurang & 4 & 11.8 & 28 & 82.4 \\
\hline
\end{tabular}

\section{Perbedaan Rata-Rata Penurunan}

Tekanan Darah Sebelum Dan Sesudah

\section{Perlakuan}

Perbedaan rata-rata penurunan tekanan darah sebelum dan sesudah pada kelompok perlakuan dan kelompok kontrol disajikan dalam tabel 3 .

Tabel 3. Perbedaan rata-rata penurunan tekanan darah sebelum dan sesudah

\begin{tabular}{lllll}
\hline & & $\begin{array}{l}\text { Mean } \\
\text { awal } \\
\mathbf{\pm S D}\end{array}$ & $\begin{array}{l}\text { Mean } \\
\text { akhir } \\
\mathbf{\pm S D}\end{array}$ & $\begin{array}{l}\text { Selisih } \\
\text { rata-rata }\end{array}$ \\
\hline Perlakuan & Sistolik & $146.47 \pm$ & 133.68 & 12.79 \\
& & 10.977 & \pm & $\mathrm{mmHg}$ \\
& & & 12.142 & \\
& Diastolik & 89.26 & 83.53 & $5.73 \mathrm{mmHg}$ \\
& & \pm & \pm & \\
& & 5.440 & 5.440 & \\
\hline
\end{tabular}




\begin{tabular}{lllll}
\hline Kontrol & Sistolik & 144.41 & 145.59 & -1.18 \\
& & \pm & \pm & $\mathrm{mmHg}$ \\
& & 10.058 & 9.595 & \\
& Diastolik & 86.76 & 88.24 & -1.48 \\
& & \pm & \pm & $\mathrm{mmHg}$ \\
& & 6.382 & 6.950 & \\
\hline
\end{tabular}

Perbedaan Rata-Rata Tekanan Darah Sebelum dan SesudahPada Perlakuan

Perbedaan selisihrata-rata tekanan darah sebelum dan sesudah pada kelompok perlakuan disajikan dalam tabel 4 .

Tabel 4. Perbedaan rata-rata tekanan darah sebelum dan sesudah

\begin{tabular}{llcccc}
\hline & & $\begin{array}{c}\text { Mean } \\
\text { awal } \\
\pm \text { SD }\end{array}$ & $\begin{array}{c}\text { Mean } \\
\text { akhir } \\
\pm \text { SD }\end{array}$ & t & P \\
& & & \\
\hline $\begin{array}{l}\text { Perl } \\
\text { aku }\end{array}$ & Sistolik & 146.4 & $133.68 \pm$ & 11.843 & .000 \\
an & & $7 \pm$ & 12.142 & & \\
& & 10.97 & & & \\
& Diastoli & 89.26 & $83.53 \pm$ & 5.910 & .000 \\
& $\mathrm{k}$ & \pm & 5.440 & & \\
& & 5.440 & & & \\
Kon & Sistolik & 144.4 & $145.59 \pm$ & -1.436 & .160 \\
trol & & $1 \pm$ & 9.595 & & \\
& & 10.05 & & & \\
& & 8 & & & \\
& Diastoli & 86.76 & $88.24 \pm$ & -1.122 & .270 \\
& $\mathrm{k}$ & \pm & 6.950 & & \\
& & 6.382 & & & \\
\hline
\end{tabular}

\section{PEMBAHASAN}

Responden dalam penelitian ini sebagian besar merupakan berjenis kelamin perempuan dengan kategori usia lebih dari atausamadengan 40tahun. Penelitian membuktikan bahwa perempuan cenderung menderita hipertensi daripada laki-laki. Setelah mengalami menopose seorang perempuan lebih beresiko untuk mengalami peningkatan tekanan darah (Anggraini, dkk, 2009)

Resiko hipertensi semakin meningkat seiring bertambahnya usia, kelompok usia>40 tahun memiliki resiko 17 kali lebih tinggi dibandingkan kelompok usia $<40$ tahun (Irza, S, 2009).

Asupan energi yang berlebih pada akhirnya disimpan dalam bentuk lemak, yang akan tersimpan dijaringan subkutan dan di jaringan usus. Kebiasaan asupan lemak berlebih tidak baik bagi kesehtan karena dapat menyebabkan obesitas sentral yang pada akhirnya dapat meningktakan resiko penyakit kardiovaskuler.

Asupan lemak dan karbohidrat yang berlebihan akan meningkatkan kadar kolesterol dalam darah yang akan tertimbun dalam tubuh dalam bentuk plak. Plak tersebut menyebabkan penyumbatan pembuluh darah (aterosklerosis) dan membuat aliran darah ke seluruh tubuh terganggu serta dapat meningkatkan volume darah dan tekanan darah (Nur,hema, A.S, 2015).

Asupan natrium yang berlebihan dapat menyebabkan meningkatnya konsentrasi natrium di dalam cairan ekstraselular, yang akan meningkatkan volume darah sehingga jantung memompa lebih kuatdan tekanan darah menjadi naik. Sebaliknya konsumsi kalium yang tinggi dapat meningkatkan ekskresi natrium, sehingga dapat menurunkan volume darah dan tekanan darah(Nezhad MJ, et al, 2009).

Kebiasaan konsumsi serat yang tinggi sangat dianjurkan dan baik untuk kesehatan karena dapat mengurangi asupan energy dan 
mengurangi resiko obesitas yang pada akhirnya menurunkan risiko tekanan darah tinggi (Baliwati, F, dkk, 2004). Asupan vitamin $\mathrm{C}$ yang tidak adekuat dapat mengakibatkan terjadinya peroksidasi lipid, meningkatkan stres oksidatif, kerja enzim meningkat sehingga tekanan darah meningkat (Nezhad, MJ, et al, 2009).

Pada kelompok kontrol didapatkan $\mathrm{p}$ value yaitu 0.160 untuk tekanan sistolik, dan 0.270 untuk tekanan diastolik, dimana $\mathrm{p}$ value $>(\alpha) 0.05$ sehingga dapat disimpulkan bahwa tidak ada pengaruh bermakna terhadap tekanan darah sebelum dan sesudah pada kelompok kontrol. Berdasarkan hasil penelitian ini, rendahnya asupan Protein, Kalium, Serat dan Vitamin $\mathrm{C}$ responden menyebabkan tekanan darah responden tidak memiliki pengaruh bermakna.

Pada kelompok perlakuan terjadi penurunan tekanan darah secara bermakna

\section{DAFTAR RUJUKAN}

Almatsier, S. 2009. Prinsip Dasar Ilmu Gizi. Gramedia . Jakarta: Penerbit PT Gramedia Pustaka Utama.

Anggraini, A, D., Waren, A., Situmorang, E., Saputra, H., Siahan, S, S. (2009). Faktor-Faktor yang berhubungan dengan kejadian Hipertensi Pada Pasien Berobat Di Poliklinik Dewasa Puskesmas BangkinangPeriode Januari sampai Juni.2008. Avalaible: Http://yayanakhyar.wordpress. com (Diakses tanggal 7 juli 2018).

Aryanti Maya. 2012. Meracik Sendiri Obat \& Menu Sehat Bagi Penderita Darah Tinggi', Edisi 1. Pustaka Baru Press, Jogjakarta.

Baliwati, Y.F., Khomsan, A., Dwiriani, C.M. 2004. Pengantar Pangan dan Gizi. Penebar Swadaya. Hal. 89 : Jakarta

Irza S. 2009. Analisis Faktor Risiko Hipertensi pada yaitu tekanan sistolik sebesar $12.79 \mathrm{mmHg}$ dan tekanan diastolik sebesar $5.73 \mathrm{mmHg}$. Semangka, tomat dan jeruk manis mengandung kalium tinggi yang dapat berfungsi sebagai diuretik dan menghambat pengeluaran renin dan membantu menormalkan tekanan darah. Berdasarkan penelitian sebelumnya mengenai vitamin $\mathrm{C}$, membuktikan bahwa vitamin $\mathrm{C}$ dapat menurunkan tekanan darah sistolik dan diastolik, sehinggaVitamin $\mathrm{C}$ dapat mengurangi resiko hipertensi.

\section{KESIMPULAN}

Konsumsi smoothie smatonis yang terbuat dari semangka, tomat dan jeruk manis secara rutin terbukti berpengaruh terhadap penurunan tekanan darah penderita Hipertensi.

Masyarakat Nagari Bungo Tanjung Sumatera Barat [skripsi]. Medan (ID): Universitas Sumatera Utara.

Monica, 2009. Hypertensive Status and Lipoprotein Oxidation in an Elderly Population at High Cardiovascular Risk. American Journal of Hypertension, vol. 22, no. 1, pp. 68-73.

Nezhad MJ, Eftekhari MH \& Aghasadeghi K. 2009. Modulation of Blood Pressure in Hypertensive Patientsby Vitamin C. Iranian Cardiovascular Research Journal, vol. 3, no. 1.

Nur, Hema.A.S. 2015. Hubungan Pengetahuan Tentang Hipertensi, Asupan Lemak Dan Natrium Dengan Status Gizi Di Posyandu Lansia, Gonilan, Kartasura, Sukoharjo. Surakarta.

Riskesdas. (2013). Hipertensi / Tekanan Darah. Available: $\quad$ http://www.depkes.go. id/resources/download/general/Hasil\%20Riske sdas\%202013.pdf 
Saseen, J.J., \& Maclaughlin, E.J.,

2009,Cardiovaskuler disorder: Hipertension, Editor:

Dipiro, J.T., Talbert, R.L., Yee, G.C., Matzke, G.R.,

Wells, B.G., Posey, L. M., Pharmacotherapy A

Pathophysiological Approach, Seventh Edition, New

York: Mcgraw-Hill Medical Publishing Division 